\title{
RAGAM PENDEKATAN DALAM MENGEMBANGAN KURIKULUM PENDIDIKAN AGAMA ISLAM (PAI)
}

\author{
Muhamad Ghazali Abdah \\ Universitas Nurul Jadid \\ muhammadghozaliabdah1987@gmail.com
}

\begin{abstract}
The curriculum is an inseparable part of an education system, because it is one component in determining the achievement of a goal. Likewise the Islamic religious education curriculum (PAI) also has a very central role in various educational processes in order to achieve the direction and purpose of Islamic education itself. Islamic education aims to develop all the potential that humans have based on the Shari'ah of Islam. However, the PAI curriculum in fact, still holds problems in life, for example the learning model is still dogmatic, repository and overlapping, and the religious concepts taught have no relevance in life in modern times today. Educators and all education staff are required to truly be able to understand the curriculum and be able to develop it. In developing an Islamic religious education curriculum (PAI) certain approaches are needed, so that the curriculum developed can lead students towards the desired changes. Educators can choose a number of approaches that are appropriate to their learning model and of course by paying attention to the characteristics of Islamic religious education itself. Among the approaches that can be used in curriculum development there are four, namely: academic, humanistic, technological and social reconstruction approaches. The developed curriculum can later be implemented by various PAI teachers in the teaching and learning process in schools.
\end{abstract}

Keywords: Approaches, Curriculum Development PAI

\section{PENDAHULUAN}

Kurikulum merupakan satu komponen yang seharusnya adadalam suatu lembaga pendidikan. ${ }^{1} \quad$ Kurikulum mempunyai peranan yang sangat penting dan strategis untuk mencapai tujuan dari pendidikan itu sendiri, baik pendidikan yang sifatnya umum maupun pendidikan Agama. ${ }^{2}$ Penyusunan kurikulum dilakukan oleh berbagai para pakar/ahli, baik ahli di bidang

${ }^{1}$ Hasan Baharun, Pengembangan Kurikulum: Teori Dan Praktik (Konsep, Prinsip, Model, Pendekatan Dan Langkah-Langkah Pengembangan Kurikulum PAI) (Yogyakarta: Cantrik Pustaka, 2017).

'Marliana, 'Anatomi Kurikulum Pendidikan Agama Islam Di Sekolah', Dinamika Ilmu, 13.2 (2013), 137-60. 
kurikulum itu sendiri, ahli di bidang pendidikan, ahli di bidang ilmu, tenaga pendidik, para pejabat pendidikan, serta unsur-unsur yang ada didalamnya. Rancangan ini disusun tidak lain untuk memberikan suatu pedoman terhadap para pelaksana pendidikan, dalam hal proses pembinaan serta bimbingan perkembangan siswa guna mencapai tujuan sebagaimana yang telah dicita-citakan oleh siswa sendiri, keluarga, maupun masyarakat. Dan kelas merupakan salah satu tempat untuk melaksanakan dan menguji kurikulum di sekolah.

Dengan mempelajari dan memahami kurikulum, para pendidik/guru dapat menentukanserta dapatmemilih tujuan pembelajaran, memilih metode, tekhnik, media pembelajaran, serta bahan evaluasi yang tepat dan sesuai dalam pembelajaran. Maka dari itu, untuk melakukan sebuah kajian terhadap keberhasilan dalam sistem pendidikan harus dilakukan oleh berbagai pihak, sarana yang memadai, organisasi yang baik, dan intensitas pekerjaan yangmemiliki realistis tinggi, serta kurikulum yang relevan dan tepat guna.

Oleh sebab itu, para pendidik dan juga tenaga kependidikan, khususnya dibidang pendidikan Islam sudah sewajarnya dapat memahami arah dan tujuan kurikulum, serta berusaha mengembangkannya.Kurikulum dalam hal ini membutuhkan suatu landasan yang kuat agar nantinya dapat dikembangkan oleh berbagai pihak sekolah maupun berbagai lembaga formal lainnya.

Kurikulum Pendidikan Agama Islam (PAI) mempunyai kedudukan yang sentral terhadap seluruh proses pendidikan, sebagai arah segala aktifitas pendidikan demi tercapainya tujuan. Selain sebagai rencana pendidikan, kurikulum juga merupakan suatu pedoman dan juga pegangan terhadap jenis, ruang lingkup dan urutan isi serta strategi dalam proses pendidikan. Fungsi lainnya adalah menjadi sumber konsep serta landasan teoritis bagi para pengembangan kurikulum dalam institusi pendidikan.

Namun pada kenyataanya, kurikulum masih menyimpan berbagai persoalan. Misalnya diantaranya, kurikulum Pendidikan Agama Islam (PAI) saat ini banyak yang tumpang tindih, repitikal, dogmatis dan pada bagian 
tertentu, konsep keagamaan yang diajarkan tidak ada relevansinya dengan kehidupan zaman modern ini.

Model Pengembangan Kurikulum PAI harus benar-benar diperhatikan, lebih-lebih dalam aplikasinya. Karena selama pemahaman masyarakat beranggapan bahwa, dengan kehadiran PAI di sekolah diharapkan mampu memadukan seluruh aspek-aspek keilmuan, baik dari segi IPTEK maupum IMTAQ terhadap peserta didik di sekolah. ${ }^{3}$

Anggapan seperti haruslah benar-benar diperhatikan, lebih-lebih dalam penerapannya khususnya ketika proses kegiatan belajar mengajar berlangsung, karena bila tidak diperhatikan, maka bisa berakibat fatal terhadap keberlanjutan kurikulum Pendidikan Agama Islam itu sendiri. Sebagaimana kita sadari bahwa, saat ini peran Pendidikan Agama Islambukan hanya sekedar mengutamakan pendidikan agama saja, tetapi lebih diharapkan adanya perpaduan yang berkesinambungan antara pendidikan agama dan pendidikan umum.

Maka dari itulah, kurikulum tentunya harus mempunyai landasan yang kuat dalam mengembangkannya, sebab jika kurikulum diibaratkan seperti sebuah bangungan yang tidak memiliki pondasi atau landasan yang kuat, maka akan mudah roboh dikala angin dan badai menerpanya. Demikian halnya dengan kurikulum jika tidak memiliki landasan yang kuat yang bisa dijadikan pijakan, maka yang akan terjadi pada kurikulum tersebut akan terombang-ambing dan yang menjadi korban nantinya adalah peserta didik itu sendiri. ${ }^{4}$

\section{PENGERTIAN KURIKULUM}

Kurikulum berasal dari bahasa latin, yakni "currere" yang diartikan sebagai tempat untuk berlari. Sedangkan definisi kurikulum dalam arti sempit adalah sebagai subjek atau mata pelajaran yang nantinyaakan dipelajari. Sebenarnya istilah kurikulum ini, pada mulanya sangat populer di dunia olah

${ }^{3}$ Syahroni Hasan, 'Anatomi Kurikulum Pendidikan Agama Islam Di Sekolah', Dinamika Ilmu, 13.2 (2013), 137-60.

${ }^{4}$ Rosmiaty Azis, 'Implementasi Pengembangan Kurikulum', 2004, 44-50. 
raga, yakni "curriculae" yang dalam bahasa latin diartikan sebagai suatu jarak (batasan akhir) yang harus dicapai oleh seorang pelari dalam suatu perlombaan, mulai dari garisstart (awal) hinggafinish (akhir). Dari istilah tersebut, kurikulum masuk kedalam dunia pendidikan dan kemudian didefinisikan sebagai sekumpulan mata pelajaran di sekolah maupun mata kuliah di perguruan tinggi, yang harus ditempuh sebagai proses untuk memperoleh ijazah. ${ }^{5}$

Sementara itu, menurut peraturan pemerintah No. 19 Tahun 2005 tentang Standar Nasional Pendidikan (SNP), kurikulum diartikan sebagai seperangkat perencanaan dan pengaturan mengenai suatu tujuan, isi dan materi bahan pelajaran, serta konsep yang akan digunakan sebagai pedoman dalam penyelenggaraan kegiatan pembelajaran guna mencapai suatu tujuan dalam jenjang pendidikan tertentu.

Kurikulum merupakan sejumlah mata pelajaran tertentu yang nantinya harus dipelajari dan dicapai oleh siswa guna memperoleh sejumlah pengetahuan. ${ }^{6}$ Mata pelajaran (subject matter), dipandang sebagai pengalaman orang-orang pandai dimasa lampau atau penemuan-penemuan di masa lampau, yang kemudian diadakan penyeleksian yang ketat dan selanjutnya, disusun secara sistematis, dalam artian menurut urutan tertentu, serta dapat diterima oleh akal pikiran secara rasional. Mata pelajaran merupakan sekumpulan materi pembahasan yang akan diajarkan kepada siswa nantinya, sehingga mereka memperoleh berbagai ilmu pengetahuan yang berguna baginya. $^{7}$ Semakin banyak pengalaman-pengalaman dan penemuanpenemuan yang diperoleh dan terkandung didalamnyajuga akansemakin banyak, maka mata pelajaran harus disusun dan dikembangkan didalam kurikulum yang nantinya juga harus dipelajari dan dicapai oleh siswa disekolah. ${ }^{8}$

\footnotetext{
${ }^{5}$ Muhamad Tisna Nugraha, 'Pengembangan Model Kurikulum Pendidikan Agama Islam (PAI) Menuju Ekonomi Asean (MEA)', At-Turats, 10.1 (2016).

${ }^{6}$ Reni Uswatun Hasanah Akmal Mundziri, 'Inovasi Pengembangan Kurikulum Pai Di Smp Nurul Jadid', Tadrib, IV (2018), 41-68.

${ }^{7}$ Syafiqiyah Adhimiy Hasan Baharun, 'Curriculum Development Throught Creative Lesson Plan', Cendikia, 16.1 (2018), 41-62.

${ }^{8}$ Oemar Hamalik, Proses Belajar Mengajar (Jakarta: PT. Bumi Aksara., 2009).
} 
Menurut Sukmadinata, kurikulum dapat didefinisikan sebagai suatu upaya untuk menyusun kurikulum yang sama sekali masih baru (curriculum construction) dan bisa juga untuk menyempurnakan kurikulum yang sudah ada (curriculum improvement). Pengembangan kurikulum pada dasarnya merupakan proses penyusunan terhadap seluruh perangkat kurikulum mulai dari dasardasar kurikulum, struktur kurikulum, kumpulan mata pelajaran, hinggagarisgaris besar program pengajaran, sampai pada pedoman-pedoman pelaksanaannya (macro curriculum). ${ }^{9}$

Dengan demikian, kurikulum dalam arti sempit dapat diartikan sebagai materi pelajaran, sedangkan dalam arti yang luas dapat diartikan sebagai segala rencana dan upaya yang dilakukan dalamsebuah naungan lembaga pendidikan untuk mencapai tujuan dari pendidikan itu sendiri. ${ }^{10}$

Dari beberapa pengertian diatas dapat disimpulkan bahwa, kurikulum merupakan sejumlah materi/mata pelajaran yang disajikan guru kepada peserta didik yang harus dipelajari dan dicapai agar memperoleh ijazah atau naik ke tingkat/jenjang yang lebih tinggi. Dengan demikian kurikulum bisa dikatakan sebagai, "seperangkat rencana pembelajaran di sekolah", yang disajikan guru kepada peserta didiknya. ${ }^{11}$

\section{PENGERTIAN PENDIDIKAN ISLAM DAN PENDIDIKAN AGAMA ISLAM}

Pendidikan Islam dapat diartikan sebagai suatu proses atau upaya mengajar dan mendidik ajaran Islam agar menjadi panutan serta pandangan hidup bagi pribadi seorang muslim. ${ }^{12}$ Toumy Al-Syaibany mendefinisikan bahwa, Pendidikan Islam adalah sebagai suatu usaha untuk mengubah tingkah laku dalam kehidupan, baik kehidupan secara individu maupun

${ }^{9}$ Syamsul Bahri, 'Pengembangan Tujuan Dasar Dan Tujuannya', Jurnal Ilmiah Islam Futura, XI.1 (2011).

${ }^{10} \mathrm{H}$. Syaiful Sagala, 'PENGEMBANGAN DAN IMPLEMENTASI KURIKULUM PENTING UNTUK MENINGKATKAN KUALITAS PEMBELAJARAN', J Exp Med, 165.5 (1987)

${ }^{11}$ Nur Ahid, 'Konsep Dan Teori Kurikulum Dalam Dunia Pendidikan', ISLAMICA: Jurnal Studi Keislaman, 1.1 (2014), 12

${ }^{12}$ Suwadi Suwadi, 'Pengembangan Kurikulum Pendidikan Agama Islam Pada Pendidikan Tinggi’, Jurnal Pendidikan Agama Islam, 13.2 (2017), 223-52. 
bermasyarakat, serta mampu berinteraksi dengan alam sekitarnya melalui proses pendidikan. Sementara Ahmad Tafsir mendefinisikan Pendidikan Islam adalah sebagai bimbingan dari seseorang terhadap orang lain agar potensi yang dimilikinya dapat berkembang secara maksimal sesuai dengan syari'at Islam.

Ditinjau dari beberapa definisi tersebut diatas, dapat disimpulkan bahwa, pendidikan Islam merupakan bimbingan secara sadar dalam rangka menumbuhkembangkan potensi atau kemampuan yang dimiliki seseorang (peserta didik) sesuai dengan tuntunan syari'at Islam. ${ }^{13}$

Terkait dengan pendidikan agama Islam Chabib Thoha dan Abdul Mu'thi memberikan pengertian bahwa pendidikan agama Islam ialah upaya sadar dalam mempersiapkan peserta didik melalui kegiatan pembinaan dan pengajaran atau latihan-latihan agar dapat memahami, meyakini dan menghayati serta mengamalkan nilai-nilai ajaran Islam dengan memperhatikan tuntunan untuk saling menghormati agama lain. ${ }^{14}$

Dengan demikian Pendidikan Agama Islam (PAI) merupakan upaya sadar dan terencana dalam mempersiapkan peserta didik agar dapat mengenal, memahami, menghayati, mengimani, hingga mampu melaksanakan ajaran Islam secara menyeluruh, serta diiringi dengan adanya upaya untuk saling menghargai dan menghormati penganut agama lain dalam kaitannya dengan kerukunan antar ummat beragama bukan dalam ruang lingkup aqidah dan ibadah, sehingga akan terwujud rasa persatuan dan kesatuan bangsa.

Dari pengertian tersebut, dapat dipahami bahwa pendidikan agama Islam merupakan suatu usaha pemberian bimbingan atau asuhan terhadap peserta didik agar nantinya mampu untuk dapat memahami, menghayati secara keseluruhan makna-makna, maksud dan tujuan yang terkandung dalam ajaran Islam, sehingga pada akhirnya ia dapat mengamalkannya serta menjadikan agama Islam sebagai

\footnotetext{
${ }^{13}$ Rosichin Mansur, 'PENGEMBANGAN KURIKULUM PENDIDIKAN AGAMA ISLAM MULTIKULTURAL (Suatu Prinsip-Prinsip Pengembangan) Oleh':, Jurnal Ilmiah Victarina, 10.2 (2016).

${ }^{14}$ Chabib Thoha dan Abdul Mu'thi, Proses Belajar Mengajar PBM-PAI Di Sekolah (Yogyakarta: Pustaka Pelajar, 1998).
} 
pandangan hidupnya agar memperoleh keselamatan hidup di dunia hingga di akhirat nanti. $^{15}$

\section{KURIKULUM PENDIDIKAN AGAMA ISLAM (PAI)}

Kurikulum Pendidikan Agama Islam (PAI) sebenarnya tidak ada perbedaan yang menonjol dengan kurikulum pada umumnya, hanya saja perbedaannya terletak pada isi/materi pelajarannya saja. Sebagaimana yang telah dikemukakan oleh Abdul Majid, mengatakan bahwa, kurikulum Pendidikan Agama Islam merupakan rumusan tentang tujuan dan materi pelajaran, serta evaluasi pendidikan yang bersumber dari ajaran/syari'at Agama Islam.

Pada intinya ciri khas kurikulum dalam pendidikan Islam haruslah memiliki kesesuaian dengan ajaran Islam.Oleh sebab itu, setiap hal yang mempunyai keterkaitan dengan kurikulum, termasuk tujuan, isi, metode pembelajaran dan sebagainya yang berlaku dalam pendidikan haruslah berdasarkan agama dan akhlak islami serta terisi dengan ruh ajaran Islam. Hal inilah yang membedakan antara kurikulum Pendidikan Agama Islam (PAI) dan pendidikan umum terletak pada konsepnya, yaitu proses pendidikan yang mengacu pada pembentukan manusia yang sempurna (insan al-kamil) berdasarkan prinsip ajaran Islam.

Kurikulum dikatakan baik dan relevan, bilamana dalam mencapai tujuan pendidikan Agama Islam adalah yang bersifat intergrated dan komprehensif serta mampu menjadikan Al-Qur'an dan Al-Hadits sebagai sumber utama didalam penyusunannya.

Dalam Al-Qur'an ditemukan beberapa konsep/kerangka dasar yang bisa dijadikan sebagai rujukan atau pedoman operasional dalam penyusunan serta pengembangan kurikulum Pendidikan Agama Islam, sebagaimana yang dijelaskan dalam surat Luqman ayat: 13-19 adalah meliputi aspek tauhid (ayat : 13), syari'ah (ayat : 17) dan akhlaq (ayat 14, 18 dan 19). Dengan demikian materi PAI secara garis besar, dapat dibagi menjadi tiga pokok bahasan, yaitu :
1) Iman (Aqidah)
2) Islam (Syari'ah)
3) Ihsan (Akhlaq)

\footnotetext{
${ }^{15}$ Samrin, 'PENDIDIKAN AGAMA ISLAM DALAM SISTEM PENDIDIKAN NASIONAL DI INDONESIA', Al-Ta'dib, 8.1 (2015), 101-16.
} 
Materi-materi tersebut dijabarkan dalam kurikulum Pendidikan Agama Islam (PAI) dan kurikulum PAI sendiri merupakan pesan keislaman yang digunakan di lembaga-lembaga pendidikan untuk mencapai suatu tujuan dan oleh sebab itu, materi tersebut harus menjadi pedoman bagi guru dalam pelaksanaan pembelajaran.

\section{PENDEKATAN DAN PENGEMBANGAN KURIKULUM}

Terkait dengan definisi pengembangan kurikulum, didalam kamus besar bahasa Indonesia, kata pengembangan secara etimologi dapat diartikan sebagai pembangunan secara bertahap dan teratur yang mengarah kepada maksud dan tujuan yang hendak dicapai. Sedangkan secara terminologi, kata pengembangan didefinisikan sebagai suatu bentuk kegiatan yang menghasilkan suatu rancangan maupun produk yang dapat digunakan untuk memecahkan masalah-masalah aktual. ${ }^{16}$

Pengembangan kurikulum merupakan sebuah perencanaan dalam kesempatan-kesempatan pembelajaran yang dilakukan untuk dapat membimbing peserta didik menuju kearah perubahan-perubahan yang diharapkan serta mampu menilai seberapa besar dampak dari perubahan tersebut pada diri peserta didik. ${ }^{17}$

Pendidikan Agama Islam (PAI) juga berupaya mewujudkan penanaman nilai-nilai keimanan serta memberikan pembinaan dan pengajaran kepada peserta didik agar ia senantiasa mampu memahami dan mengamalkan ajaran Islam seutuhnya.

Kurikulum Pendidikan Agama Islam (PAI) yang sudah dikembangkan di sekolah, selanjutnya dilaksanakan oleh semua guru PAI pada setiap satuan pendidikan dengan menggunakan prinsip-prinsip pembelajaran yang baik dan mendidik. $^{18}$

${ }^{16}$ Kamus Bahasa Indonesia, ed. by Tim Penyusun Kamus Pustaka Bahasa (Jakarta: Pusat Bahasa, 2008).

${ }^{17}$ Ali Usmar, 'Model-Model Pengembangan Kurikulum Dalam Proses Kegiatan Belajar', Jurnal An-Nahdhah, 11.2 (2017). Magnum Pustaka.

${ }_{18}$ Raharjo, Rahmad. 2010. Inovasi Kurikulum Pendidikan Agama Islam. Yogyakarta: 
PENDEKATAN-PENDEKATAN

\section{KURIKULUM PAI}

Dalam mengembangkan teori kurikulum terdapat empat bentuk pendekatan yang bisa digunakan dalam proses pengembangan kurikulum, diantaranya adalah: Pendekatan Subyek Akademis, Humanistis, Tekhnologis dan Rekonstruksi Sosial. Berikut penjelasannya:

a. Pendekatan Subjek Akademis

Pendekatan subjek akademis merupakan bentuk atau model tertua diantara model lainnya. Kurikulum ini bersumber dari aliran klasik (perenialisme dan esensialisme) yang berorientasi pada peristiwa di masa lampau. Pendekatan ini lebih mengutamakan bahan dan proses dalam disiplin ilmu tertentu, karena setiap dari ilmu pengetahuan memiliki sistemisasi tersendiri, sehingga terdapat perbedaan dengan sistemisasi ilmu lainnya. Pengembangan kurikulum subjek akademis dilakukan dengan cara menentukan mata pelajaran apa yang harus didahulukan untuk dipelajari peserta didik yang dibutuhkan dalam proses persiapan pengembangan disiplin ilmu. ${ }^{19}$

Kurikulum model subjek akademis ini lebih mengutamakan isi (subject matter). Isi kurikulum merupakan kumpulan dari berbagai bahan atau rencana pembelajaran.Tingkat pencapaian penguasaan materi yang diperoleh peserta didik merupakan ukuran utama dalam menilai tingkat keberhasilan belajarnya.Oleh sebab itu, penguasaan materi yang sebanyak-banyaknya merupakan suatu hal yang di proritaskan dalam proses kegiatan belajar mengajar di sekolah ${ }^{20}$ yang diterapkan guru dalam menggunakan kurikulum model ini.

Penyusunan kurikulum PAI melalui pendekatan subjek akademis dilakukan berdasarkan sistematisasi ilmu.Misalnya, untuk aspek keimanan menggunakan sistematisasi ilmu tauhid dan aqidah, sedangkan untuk aspek ibadah dan

\footnotetext{
${ }^{19}$ Sukiman, Pengembangan Kurikulum: Teori Dan Praktik Pada Perguruan Tinggi (Yogyakarta: Teras, 2009).

${ }^{20}$ Syaiful Islam and others, 'To Boost Students ' Motivation and Achievement through Blended Learning To Boost Students ' Motivation and Achievement through Blended Learning', Journal of Physics: Conf. Series, 1114 (2018), 1-11.
} 
mu'amalah menggunakan sistematisasi ilmu fiqih dan ushul fiqih, demikian seterusnya.

b. Pendekatan Humanistik

Pendekatan humanistik dikembangkan oleh para pakar pendidikan humanisme.Kurikulum ini berdasarkan pada konsep aliran pribadi (personalized education), yaitu Jhon Dewey (Progressive Education) dan J.J. Roassean (Romantic Education).Aliran ini memberikan tempat yang utama kepada siswa. Mereka bertolak dari asumsi bahwa seorang anak atau peserta didik merupakan yang pertama dan utama. Ia adalah subyek yang menjadi pusat kegiatan pendidikan. Aliran ini mempunyai keyakinan bahwa setiap anak mempunyai potensi, kemampuan dan kekuatan untuk bisa berkembang. Guru diharapkan untuk bisa membangun hubungan emosional yang baik dan komunikatif dengan peserta didiknya. ${ }^{21}$

Dalam proses penerapannya di kelas, kurikulum model humanistik menuntut seorang guru agar mempunyai hubungan emosional yang baik dengan peserta didiknya. Maka dari itu untuk dapat memperlancar proses pembelajaran, tentunya seorang guru harus dapat memberikan layanan yang optimal kepada siswa sehingga ia merasa nyaman dengan belajarnya. Guru tidak perlu memaksakan segala sesuatu yang dapat membuat siswa merasa tidak nyaman dalam belajar, karena dengan rasa aman dan nyaman inilah peserta didik akan merasa lebih mudah menjalani proses pengembangan dirinya.

Pengembangan kurikulum PAI dilakukan oleh guru dengan melibatkan peserta didik, misalnya dalam menentukan tujuan dan tema-tema pembelajaran PAI. Isi dan proses pembelajarannya akan selalu berubah disesuaikan dengan bakat dan minat yang dimiliki peserta didik secara konstektual.

Berdasarkan penjelasan tersebut dapat diketahui bahwa, kurikulum PAI dikembangkan dengan bertumpu pada kebutuhan bakat dan minat peserta didik serta memotivasi mereka agar dapat menumbuhkembangkan potensi-

${ }^{21}$ Suprihatin, 'Pendekatan Humanistik Dalam Pengembangan Kurikulum .....', POTENSIA: Jurnal Kependidikan Islam, 3.1 (2017), 82-104. 
potensi dasar atau fitrahnya, serta memberikan motivasi agar mampu mengemban amanah sebagai "abdullah" maupun sebagai "kholifatullah" di muka bumi.

c. Pendekatan Tekhnologis

Pendekatan tekhologis dalam penyusunan kurikulum atau program pendidikan, bertolak dari analisis kompetensi yang dibutuhkan untuk melaksanakan berbagai tugas atau pekerjaan tertentu. Materi yang akan diajarkan, strategi pembelajaran serta kriteria evaluasi ditetapkan sesuai dengan analisis tugas (job description). Rencana dan proses pembelajaran dirancang dengan sedemikian rupa, sehingga hasilnya dapat dievaluasi dan diukur dengan mudah, jelas dan terkontrol. Dalam menyusun kurikulum, seharusnya tidak semua materi pelajaran dapat menggunakan pendekatan teknologis, karena sifat atau karakter dari setiap materi pelajaran itu berbeda. ${ }^{22}$ Kurikulum perspektif teknologis lebih menekankan terhadap efektivitas program, metode dan materi dalam mencapai suatu tujuan dan keberhasilan. Aplikasi teknologi merupakan sebuah rencana penggunaan berbagai macam alat dan media, serta tahapan berbasis intruksi. Sebagai teori, teknologi dapat digunakan dalam pengembangan serta evaluasi materi kurikulum dan intruksional.

Dalam pengertian teknologi sistem, model kurikulum yang akan dikembangkan harus lebih ditekankan terhadap upaya penyusunan program pengajaran atau rencana pembelajaran yang dipadukan dengan berbagai alat dan media pembelajaran yang mengikuti perkembangan zaman dalam kaitannya dengan teknologi. Sedangkan dalam pengertian teknologi alat, model pengembangan kurikulumnya berisi tentang sekumpulan rencana pembelajaran yang dilengkapi dengan menggunakan alat-alat teknologi untuk dapat menunjang efisiensi dan efektivitas pendidikan yang salah satu diantaranya merupakan pembelajaran yang menggunakan media teknologi.

Pembelajaran PAI yang menggunakan pendekatan teknologis, tentunya dalam menganalisis masalah belajar, merencanakan, mengelola,

\footnotetext{
${ }^{22}$ Muhammad Zaini, Pengembangan Kurikulum, Konsep Implementasi, Evaluasi Dan Inovasi (Yogyakarta: Teras, 2009).
} 
melaksanakan hingga menilai proses pembelajarannya dengan menggunakan pendekatan sistem. Disamping itu juga, pendekatan teknologis ingin memperoleh kemanfaatan tertentu, sehingga proses dan hasilnya selanjutnya akan diprogram sedemikian rupa, agar pencapaian dari hasil pembelajarannya dapat dievaluasi dan diukur dengan jelas dan terkontrol, serta diharapkan untuk dapat dilaksanakan secara efektif dan efesien serta memiliki daya tarik. ${ }^{23}$

d. Pendekatan Rekonstruksi Sosial

Pendekatan rekonstruksi sosial sangat memperhatikan hubungan timbal balik antara kurikulum dengan kegiatan sosial kemasyarakatan. Kurikulum model ini dikembangkan oleh aliran interaksional. Para pakar dibidang ini berpendapat bahwa, pendidikan merupakan upaya kebersamaan dari berbagai pihak demi menumbuhkan adanya interaksi dan salingbekerjasama. Istilah interaksi mempunyai makna yang luas, yaitu tidak hanya mencangkup interaksi antara guru dan siswa, tetapi juga meliputi interaksi antar siswa hingga interaksi dengan orang-orang dan lingkungan sekitarnya dengan berbagai bahan dan sumber belajar. Melalui interaksi dan kerjasama inilah peserta didik akan berusaha menyelesaikan berbagai persoalan yang terjadi di lingkungan masyarakat dan sekolah tidak hanya mengembangkan kehidupan sosial siswa, tetapi juga mengarahkan pada bagaimana siswa dapat berpartisipasi dalam kehidupan sosial.

Dalam prakteknya, perancang kurikulum ini berusaha memadukan antara tujuan pendidikan nasional dengan tujuan yang dicita-citakan siswa. Dan peran guru disini adalah membantu siswa untuk dapat menumbuhkembangkan bakat dan minatnya, serta membantu mereka agar mampu memecahkan masalah-masalah sosial. Kurikulum model ini lebih mengutamakan adanya unsur kerjasama dalam proses pembelajaran, baik kerjasama antar individu maupun kerjasama antar kelompok. Isi pendidikan terdiri dari berbagai problem aktual yang saat ini sedang dihadapi dalam kehidupan nyata. Sebagai hasil pembelajaran, diharapkan siswa dapat

${ }^{23}$ Muhammad Irsad, 'PENGEMBANGAN KURIKULUM PENDIDIKAN AGAMA ISLAM DI MADRASAH (Studi Atas Pemikiran Muhaimin)', Iqra', 2.1 (2016), 231-67. 
menciptakan dan mempersiapkan model kehidupan sosial yang dapat diaplikasikan dalam situasi yang akan datang.

Dengan demikian dalam penyusunan atau program PAI bertolak dari persoalan-persoalan yang dihadapi di masyarakat sebagai isi dari program Pendidikan Agama Islam (PAI) itu sendiri. Sedangkan proses maupun pengalaman belajar yang diperoleh peserta didik adalah dengan cara memanfaatkan berbagai ilmu dan teknologi yang ada, serta bekerja secara kooperatif dan kolaboratif dengan berupaya mencari solusi agar dapat memecahkan berbagai problematika yang terjadi di masyarakat, sehingga menjadikan kehidupan masyarakat yang lebih baik.

\section{KESIMPULAN}

Berdasarkan penjelasan diatas dapat dipahami bahwa, kurikulum merupakan salah satu komponen yang tidak dapat dipisahkan dan sangat menentukan sekali dalam suatu sistem pendidikan. Hal ini menunjukkan bahwa, kurikulum merupakan alat dalam mencapai suatu tujuan pendidikan yang sekaligus juga menjadi pedoman dalam berbagairencana pelaksanaan pembelajaran pada semua tingkatan dalam jenjang pendidikan. Setiap pendidik harus mampu memahami perkembangan kurikulum itu sendiri, karena hal itu merupakan suatu formulasi pedagogis yang sangat penting dalam kaitannya dengan pendidikan, sehingga kurikulum akan mampu diilustrasikan bagaimana seharusnya usaha yang dilakukan agar dapat membantu peserta didik dalam mengembangkan potensinya, baik berupa intelektual, spiritual, emosional, dan sosial. Dalam penyusunan pembaharuan kurikulum Pendidikan Agama Islam (PAI) dapat dilakukan dengan menginternalisasikan nilai-nilai keislaman kedalam berbagai mata pelajaran di suatu lembaga pendidikan. Oleh karena itu, diperlukan suatu pendekatan yang komprehensif dan terpadu untuk dapat mengembangkan kapasitas dan kapabelitas siswa secara maksimal. 


\section{DAFTAR PUSTAKA}

Ahid, Nur, 'Konsep Dan Teori Kurikulum Dalam Dunia Pendidikan', ISLAMICA: Jurnal Studi Keislaman, 1 (2014), 12

Akmal Mundziri, Reni Uswatun Hasanah, 'Inovasi Pengembangan Kurikulum Pai Di Smp Nurul Jadid', Tadrib, IV (2018), 41-68

Ali Usmar, 'Model-Model Pengembangan Kurikulum Dalam Proses Kegiatan Belajar', Jurnal An-Nabdhah, 11 (2017)

Azis, Rosmiaty, 'Implementasi Pengembangan Kurikulum', 2004, 44-50

Baharun, Hasan, Pengembangan Kurikulum: Teori Dan Praktik (Konsep, Prinsip, Model, Pendekatan Dan Langkah-Langkah Pengembangan Kurikulum PAI) (Yogyakarta: Cantrik Pustaka, 2017)

Bahri, Syamsul, 'Pengembangan Tujuan Dasar Dan Tujuannya', Jurnal Ilmiah Islam Futura, XI (2011)

Chabib Thoha dan Abdul Mu'thi, Proses Belajar Mengajar PBM-PAI Di Sekolab (Yogyakarta: Pustaka Pelajar, 1998)

H. Syaiful Sagala, 'PENGEMBANGAN DAN IMPLEMENTASI KURIKULUM PENTING UNTUK MENINGKATKAN KUALITAS PEMBELAJARAN', J Exp Med, 165 (1987)

Hamalik, Oemar, Proses Belajar Mengajar (Jakarta: PT. Bumi Aksara., 2009)

Hasan Baharun, Syafiqiyah Adhimiy, 'Curriculum Development Throught Creative Lesson Plan', Cendikia, 16 (2018), 41-62

Hasan, Syahroni, 'Anatomi Kurikulum Pendidikan Agama Islam Di Sekolah', Dinamika Ilmu, 13 (2013), 137-60

Irsad, Muhammad, 'PENGEMBANGAN KURIKULUM PENDIDIKAN AGAMA ISLAM DI MADRASAH (Studi Atas Pemikiran Muhaimin)', Iqra', 2 (2016), 231-67

Islam, Syaiful, Hasan Baharun, Chusnul Muali, and Ismail Marzuki Ghufron, Moh Idil, 'To Boost Students' Motivation and Achievement through Blended Learning To Boost Students' Motivation and Achievement through Blended Learning', Journal of Physics: Conf. Series, 1114 (2018), 1-11

Khuzaimah, 'Paradigma Pengembangan Kurikulum Pendidikan Agama Islam Di Sekolah (Analisis Berbagai Kritik Terhadap PAI)', Pendidikan, V (2017), 105-18

Majid, Abdul, Pendidikan Agama Islam Berbasis Kompetensi (Bandung: Remaja Rosda Karya., 2004)

Mansur, Rosichin, 'PENGEMBANGAN KURIKULUM PENDIDIKAN AGAMA ISLAM MULTIKULTURAL (Suatu Prinsip-Prinsip Pengembangan) Oleh': Jumal Ilmiah Victarina, 10 (2016)

Marliana, 'Anatomi Kurikulum Pendidikan Agama Islam Di Sekolah', Dinamika Ilmu, 13 (2013), 137-60

Nugraha, Muhamad Tisna, 'Pengembangan Model Kurikulum Pendidikan Agama Islam (PAI) Menuju Ekonomi Asean (MEA)', At-Turats, 10 (2016), 21

Nurmadiah, 'Kurikulum Pendidikan Agama Islam', Al-Afkar, III (2014)

Samrin, 'PENDIDIKAN AGAMA ISLAM DALAM SISTEM PENDIDIKAN NASIONAL DI INDONESIA', Al-Ta'dib, 8 (2015), 101-16 
Sukiman, Pengembangan Kurikulum: Teori Dan Praktik Pada Perguruan Tinggi (Yogyakarta: Teras, 2009)

Suprihatin, 'Pendekatan Humanistik Dalam Pengembangan Kurikulum .....', POTENSIA: Jurnal Kependidikan Islam, 3 (2017), 82-104

Suwadi, Suwadi, 'Pengembangan Kurikulum Pendidikan Agama Islam Pada Pendidikan Tinggi', Jurnal Pendidikan Agama Islam, 13 (2017), 223-52

Tim Penyusun Kamus Pustaka Bahasa, ed., Kamus Bahasa Indonesia (Jakarta: Pusat Bahasa, 2008)

Zaini, Muhammad, Pengembangan Kurikulum, Konsep Implementasi, Evaluasi Dan Inovasi (Yogyakarta: Teras, 2009) 